\title{
A paradiplomacia financeira no Brasil da República Velha, 1890-1930
}

\author{
Financial paradiplomacy in Brazil during \\ the Old Republic, 1890-1930
}

JOSÉ NELSON BESSA MAIA*

JOSÉ FLÁVIO SOMBRA SARAIVA**

Rev. Bras. Polít. Int. 55 (1): 106-134 [2012]

\section{Introdução}

Com a queda da monarquia no Brasil em 1889, desmantelou-se o estado unitário e seguiu-se a chamada "República Velha" (1890-1930), quando se implantou o regime federativo, sendo a Constituição de 1891 seu primeiro marco institucional. Seguiram-se 40 anos de descentralização federativa em que os estados brasileiros, livres das amarras do poder central, exercitaram certo protagonismo nos mercados internacionais de capitais ao captar vultosas somas com a emissão de títulos nas praças financeiras europeias e depois nos Estados Unidos da América (EUA). Essa exuberante fase termina com a Revolução de 1930, abrindo um novo período centralizador que culmina com a ditadura do Estado Novo (1937-1945).

Dadas as evidências disponíveis da forte atuação dos governos estaduais nos fluxos financeiros internacionais em período tão extenso, busca-se neste artigo analisar a extroversão de entes subnacionais no campo da captação de recursos externos em uma das fases da História do Brasil bem marcada pela descentralização fiscal e acesso dos entes federados brasileiros ao endividamento no exterior, ou seja, o período denominado por convenção como República Velha, e também pela abertura mais ampla da economia primário-exportadora brasileira aos fluxos de comércio, investimento e finanças mundializados no final do século 19 e início do século $20 .{ }^{1}$

\footnotetext{
* Bacharel em Economia pela Universidade Federal do Ceará (UFC), mestre em Economia pela Universidade de Brasília (UnB) e doutorando em Relaçōes Internacionais pela mesma instituição (nbessamaia@gmail.com).

** Bacharel em Relações Internacionais pela Universidade de Brasília (UnB), mestre em Relações Internacionais pelo Colégio de México e PhD em Relaçôes Internacionais pela University of Birmingham, Reino Unido. Professor titular no Instituto de Relações Internacionais da Universidade de Brasília (IREL/UnB) e pesquisador do Conselho Nacional de Desenvolvimento Científico e Tecnológico (CNPq) (fsaraiva@unb.br).

1 Ao longo da República Velha, que é a denominação convencional para a história republicana que vai da proclamação (1889) até a ascensão de Getúlio Vargas em 1930, o Brasil conheceu uma sequência de 13 presidentes. $\mathrm{O}$ traço mais saliente dessa primeira fase republicana encontra-se no fato de que a política esteve inteiramente dominada pela oligarquia cafeeira, em cujo nome e interesse o poder foi de fato exercido. Para uma caracterização mais completa da "República Velha", ver Del Priore e Venâncio (2001), especialmente p. 300-310.
} 


\section{A paradiplomacia financeira: aspectos teóricos e conceituais}

Soldatos (1990), ao analisar a atuação dos governos subnacionais no cenário internacional, cunhou o termo "paradiplomacia" para designar as investidas desses governos no exterior. O termo foi divulgado por Duchacek (1988), o qual abandonou sua própria terminologia "microdiplomacia", por reconhecer que o termo poderia ser considerado depreciativo, e preferiu adotar a denominação de Soldatos, que praticamente passou a prevalecer na literatura especializada. Duchacek estabeleceu diferenças entre a paradiplomacia transfronteiriça, a transregional (sem fronteira comum) e a global (que inclui relações com todo o mundo).

Duchacek e Soldatos encontraram o marco teórico adequado para analisar e interpretar a atividade internacional crescente dos governos não centrais no chamado "enfoque global transnacional" e na noção de "interdependência complexa" proposta nos ensaios teóricos de Robert Keohane e Joseph Nye, os quais, ao contestarem o Realismo, defenderam nova agenda nas Relações Internacionais, caracterizada por número crescente de temas complexos, sem clara hierarquia ou fácil solução, que englobam todos os níveis de governo. Com efeito, Keohane e Nye (1977), analisando as várias conexôes internacionais, falam em interdependência complexa entre Estados e sociedades, salientando que aumentaram as conexóes econômicas e decresceram as de segurança. De certo modo, os autores lançam as Relações Internacionais para a área da Economia Política Internacional (EPI), mas, mantendo algumas das heranças do Realismo, posto que ainda situam os estados no centro das relações internacionais.

Assim, Keohane e Nye foram um dos primeiros autores a questionar o modelo estatocêntrico de ator unitário na cena internacional, reconhecendo que a política mundial se desenvolve em um mundo mais complexo de relaçôes interdependentes, formais e informais, que se dão não só entre Estados-Nação, como também entre corporações privadas e organismos internacionais. Ainda que os dois autores não abordem especificamente o tema do envolvimento das entidades subnacionais em assuntos internacionais, seus ensaios apoiam a ideia de que cada nível de governo continuará desempenhando uma função vital na satisfação de demandas e, de maneira especial, quando a política interna assume aspectos internacionais.

Dada a ampla difusão do termo "paradiplomacia" nos meios acadêmicos, governamentais e de organismos internacionais, ele será empregado neste artigo conforme definição de Prieto $(2004,251)$ para expressar:

O envolvimento de governo subnacional nas relações internacionais, por meio do estabelecimento de contatos, formais e informais, permanentes ou provisórios com entidades estrangeiras públicas e privadas, objetivando promover resultados sócio-econômicos (promover exportaçōes, atrair investimentos, divulgar o turismo, captar recursos financeiros e obter cooperação técnica, grifo nosso), bem como qualquer outra dimensão externa de sua própria competência constitucional. 
Com base nessa definição geral, conceitua-se paradiplomacia financeira como "a iniciativa própria e autônoma de um governo subnacional no sentido de negociar diretamente a captação de créditos de médio e longo prazo ofertados por fontes internacionais e/ou estrangeiras com vistas a complementar suas necessidades de financiamento".

O conceito de paradiplomacia surge, portanto, no final dos anos 1980, retratando a realidade do final do século 20. No entanto, o fenômeno teria ocorrido em outros momentos históricos caracterizados por expansão das relaçōes econômicas internacionais, como foi o final do século 19 até a $1^{\text {a }}$ Guerra Mundial. Autores antigos como Fournier de Flaix (1883), Leroy Beulieu (1883) e Amaro Cavalcanti $(1900)^{2}$ já chamavam atenção para as ações dos governos "provinciais" na esfera internacional, inclusive no campo dos empréstimos externos e os riscos que isso podia acarretar para os respectivos governos centrais na ausência da supervisão pelo poder nacional.

Vê-se, portanto, que a ação dos governos não centrais nas relações financeiras internacionais não se limita ao final do século 20 ou à primeira década do século 21, mas também teria sido relevante e motivo de preocupação no final do século 19 e começo do século seguinte. Trata-se, assim, de aplicar um conceito atual, ajustado à realidade da globalização econômica, à ocorrida em um período pretérito marcado pela mundialização das relaçôes econômicas, a chamada "Idade do Ouro do capitalismo global triunfante" (Frieden 2006, 32).

Dado o exposto, este artigo analisa o processo de captação de recursos externos pelos estados brasileiros durante a República Velha (1890-1930), à luz da conceituação moderna da paradiplomacia, defendendo o argumento de que a experiência histórica do Brasil nesse campo teria sido um caso de paradiplomacia financeira cuja dimensão e durabilidade no tempo poderiam se comparar ao processo similar transcorrido no País desde o final dos anos 1980 até o momento em que os governos não centrais brasileiros (estados e municípios) voltaram a captar vultosas somas de empréstimos no exterior, exercitando, dessa maneira, um dos aspectos mais importantes da paradiplomacia.

\section{A mundialização das finanças no final do século 19 e a paradiplomacia financeira na República Velha}

De 1870 a 1914, surgiu uma economia global pela primeira vez, estendendo-se do coração industrial da Europa Ocidental (Reino Unido, França e Holanda) aos países retardatários do Velho Continente (Alemanha, Rússia) à América (EUA),

2 As referências precisas são as seguintes obras: i) BEAULIEU, Leroy. L'État moderne et ses fonctions, Paris: Guillaumin Cie Librairies, 1889; ii) DE FLAIX, Fournier. Études économiques et financières (2 volumes) Guillaumin Cie Libraries, 1883; e iii) CAVALCANTI, Amaro (1900). Regimen Federativo: a Republica Brazileira. Rio de janeiro: Imprensa Nacional, 1900. 
ao Oriente (Japão) e aos fornecedores de matérias-primas da então periferia capitalista (Argentina, Austrália, Brasil, Canadá etc.). No centro da ampliação do comércio internacional estava uma engrenagem de altas finanças que viabilizava a implantação de ferrovias e infraestruturas urbanas e portuárias e abria novas áreas para a produção primária. Assim, fluxos de capitais estrangeiros forneciam a poupança e as divisas requeridas para importar trilhos, locomotivas e equipamentos que estavam além da capacidade dos países recipientes.

Para os fornecedores de capitais, tais fluxos eram expressivos. A Grã-Bretanha, a maior fonte individual de capital estrangeiro, investia no exterior uma soma anual ao redor da média de 5\% do PIB durante o período 1873-1913, tendo chegado à marca de quase $10 \%$ do PIB às vésperas da Primeira Guerra Mundial. De fato, no início dos anos 1880, o mercado inglês de capitais dispunha de ampla massa de recursos financeiros e buscava a abertura de novas áreas de investimento, não sujeitas à severa concorrência a que os produtores e capitais do Reino Unido estavam sendo submetidos na Europa Ocidental. Como resultado, as taxas de juros reais haviam diminuído na Europa, estimulando a exportação de capitais. ${ }^{3}$

No caso da França, após o pagamento das reparações de sua derrota na guerra franco-prussiana de 1870-1871, a transferência de capitais para o exterior aumentou após 1880, chegando à metade da média britânica, e uma terça parte se destinava a financiar a industrialização da Rússia czarista. A Alemanha, por seu turno, que se unificara em 1871, e se industrializava de forma acelerada, era investidor retardatário, mas assim mesmo já competia com ingleses, franceses e holandeses por aplicações em títulos de dívida de governos na América do Sul. No todo, o investimento europeu no subcontinente saltou de $£ 44,1$ milhōes, entre 1873-1882, para $£ 182$ milhões, no período de 1883-1891, grande parte dos quais foram para a Argentina, então o país mais desenvolvido da região (Filomeno 2007, 2).

No entanto, logo na primeira década do século 20, algumas transformações em curso já começavam a operar no cenário econômico internacional com o surgimento dos EUA como exportador de capitais. Conforme assinala Albert Fishlow $(1985,384)$ :

The first world war marked a decisive break. For one, it marked the emergence of the United States for the first time as a net creditor nation. For another, the position of the principal European lenders was much changed. Germany became a leading importer of capital; French assets abroad were dramatically reduced by the [Soviet debt] repudiation of extensive Russian holdings; diminishing the appetite for overseas holdings as domestic reconstruction requirements increased; Britain experienced a marked decline in savings rates. A larger US presence did not compensate for European withdrawal, and global foreign investment declined.

3 Para uma análise mais abrangente da atuação dos capitais europeus nos países da periferia capitalista no final do século 19 e início do século 20, consultar Fishlow (1985, 383-439). 
Aproveitando-se da ampla oferta de capitais para a América do Sul, não só o governo central (imperial) brasileiro, como algumas províncias e até um município, nos últimos anos da monarquia, lograram captar expressivos volumes de recursos nos mercados de capitais europeus. Essa pioneira investida paradiplomática de governos subnacionais do Brasil rumo ao financiamento externo ocorreu em 1888, com a efetivação de operações de emissão de títulos públicos pelas províncias de Bahia, São Paulo e a municipalidade de Santos. ${ }^{4}$

\section{O regime republicano e a autonomia dos entes federados}

A instalação da República no Brasil, a partir de novembro de 1889, sacramentou o modelo federalista, transformando as antigas províncias em estados e concedendo-lhes a posição de entes políticos autônomos e com peso na operacionalização do novo pacto de poder. Em outras palavras, as condições políticas e econômicas então vigentes propiciaram mais poderes às frações de classes dominantes locais e uma estrutura tributária capaz de propiciar autonomia fiscal e administrativa aos estados recém-criados.

Diante da euforia federalista, em setembro de 1890, o então ministro da Fazenda do governo provisório, Rui Barbosa, conseguiu aprovação do marechal Deodoro da Fonseca para um Decreto pelo qual o governo federal poderia garantir empréstimos externos aos estados até o limite global de 50 mil contos de réis (equivalentes a $£ 4,7$ milhões). Conforme a exposição de motivos, a medida se justificava aos estados que não pudessem realizar operações de crédito externo em função de seu elevado risco de crédito e assegurar condiçōes contratuais minimamente aceitáveis (juros anuais e deságios máximos sobre o valor de face dos títulos representativos da operação). ${ }^{5}$

Tratava-se de tentativa de disciplinar o acesso dos estados federados aos mercados internacionais de capitais, de modo a exercer controle, salvaguardar a imagem externa do País e minimizar custos de captação por meio da concessão de garantia do governo central que reduzisse o risco de eventual inadimplência. No entanto, na mesma edição do Diário Oficial que publicou a aprovação do Decreto, foi editado "instigante" extrato de contrato entre o ministro da Fazenda e representantes de um sindicato de banqueiros ingleses, à cuja frente se achava a firma Louis Cohen \& Sons, no qual tais representantes declaram terem sido abordados por diversos funcionários dos estados federados para fazerem empréstimos e que aceitavam "emprestar aos diversos estados da União, que assim desejarem,

4 As condiçôes contratuais do pioneiro empréstimo externo tomado pela província da Bahia em 1888 foram detalhadas no texto da Mensagem à Assembleia Legislativa do então Presidente da Província, Manuel do Nascimento Machado Portela, na $1^{\text {a }}$ Sessão da $27^{\mathrm{a}}$ Legislatura da Assembleia Legislativa Provincial no dia 3 de abril de 1888. Bahia, Typ. da Gazeta da Bahia, 1888, p. AIII0 a AIII12.

5 Ver, a propósito, a íntegra do Decreto de 14 de agosto de 1890, no Diário Oficial da União, 3 de setembro de 1890 , p. 3.891 . 
as quantias de que necessitam para a satisfação de seus compromissos, promover immigração e desenvolver a sua riqueza publica, até à quantia autorizada pelo governo federal [sic]".

A primeira constituição republicana (promulgada em 24 de fevereiro de 1891) garantiu aos governos estaduais o controle da então principal fonte de arrecadação tributária - o imposto de exportação - e o direito de manipular seus tributos, de criar outros não concorrentes com a União, de recorrer à dívida pública e aos empréstimos externos, bem como atuar em qualquer área de seu interesse, respeitados os poderes expressos da União (Artigo 65, $\$ 2^{\circ}$ da Constituição Federal de 1891). Conforme assinala Fausto (1997, 121-122):

A constituição de 1891 evidencia, no plano das instituições, que a classe dominante consegue alcançar seus objetivos políticos já no início da República, e é um índice de sua capacidade para promover a integração do país na medida de tais objetivos. A ampla autonomia estadual consagrada na Constituição (possibilidade de contrair empréstimos externos, constituir milícias, discriminação de rendas favorecendo os estados, a quem cabe lançar impostos sobre a exportação, transmissão de propriedade rural, indústria e profissóes etc.) não corresponde a um esfacelamento do poder central.

Criou-se um formato tributário peculiar: de um lado, colocavam-se os estados cafeeiros (a exemplo de São Paulo, Minas Gerais, Rio de Janeiro e Paraná) que desfrutavam de sólida base financeira, com autonomia de ação em atender às demandas em épocas de crise e nas fases de crescimento e, de outro, estavam os estados sem fontes promissoras de renda (no Nordeste e no Centro-Oeste do País) e que pautavam seu relacionamento com a União como se fossem estados satélites ou clientes. Assim, durante a República Velha, a desigualdade de condiçôes econômicas entre os estados deu ao governo federal o papel de articulador da Federação e de mantenedor da reprodução global do sistema (Lopreato 2000).

Instalado o regime republicano, sobrevieram graves perturbações da nova ordem política no País, a exemplo da Revolução Federalista no Rio Grande do Sul (1893-1895) e das Revoltas da Armada (1892 e 1893), o que levou ao endurecimento do regime com o governo de exceção do marechal Floriano Peixoto (de novembro de 1891 a novembro de 1894). No campo econômico, a propagação no plano externo da crise do banco britânico Baring Brothers, desencadeada pelo default da dívida externa argentina (em 1890), e que estancou o financiamento europeu à América do Sul e, no plano interno, a crise do Encilhamento (1890-1891) e seus desdobramentos geraram graves dificuldades para a economia nacional, afastando investidores e financistas estrangeiros, temerosos da sustentabilidade do novo regime brasileiro. ${ }^{6}$

6 A chamada Crise do Encilhamento ocorreu durante o governo provisório de Deodoro da Fonseca (1889-1891). O então ministro da Fazenda, o político liberal Rui Barbosa, na tentativa de estimular a industrialização do Brasil, adotou uma política baseada em créditos livres aos investimentos industriais garantidos pelas emissōes monetárias. 
Nesse contexto de instabilidade, o Governo brasileiro, após quase quatro anos de ausência, voltou ao mercado internacional de capitais, logrando captar empréstimo de $£ 3,71$ milhōes junto à casa bancária londrina Rothschild \& Sons, sob condições draconianas, uma vez que realizado ao tipo de 80 (deságio de $20 \%$ sob o valor de face), juros de $5 \%$ ao ano e 30 anos de prazo. Na verdade, o empréstimo se destinava à compra de armamentos e munições e demais despesas militares para enfrentar as revoltas que deflagravam pelo Brasil. Conforme assinala Bouças $(1955,191)$ :

Na urgência de adquirir armamentos e munições para defender a ditadura, Floriano Peixoto, sucessor do Marechal Deodoro da Fonseca, temendo lançar um empréstimo externo, que poderia não ter êxito, serviu-se de um novo expediente que passou a ser considerado a primeira operação financeira da República no exterior, embora o empréstimo não fosse diretamente contraído pelo Tesouro Nacional.

\section{A primeira fase da paradiplomacia financeira, 1890-1913: fontes do crédito externo e sua destinação}

Em que pese à contaminação da crise do banco Baring sobre as operaçōes de empréstimos externos das províncias argentinas e as dificuldades enfrentadas pelo Brasil no início do governo de Prudente de Morais (1894-1898), governos estaduais brasileiros, valendo-se da experiência de algumas províncias que captaram recursos no exterior durante o regime imperial e do vácuo da Constituição de 1891 quanto às atribuiçôes dos governos subnacionais no campo internacional, tomaram a iniciativa de buscar financiamento externo. As vantagens de custo menor em face do estreito mercado de capitais doméstico e as pressões políticas em prol de investimentos públicos em infraestrutura urbana e de transportes levaram alguns presidentes (governadores) de estados a sondar bancos franceses e britânicos.

Tal como bem salienta Goldsmith $(1986,127)$ :

Como conseqüência dos pesados gastos com infra-estrutura, as dívidas dos estados e municípios cresceram rapidamente. Entre 1903 e 1912, os débitos estaduais aumentaram de 240 mil para quase 950 mil contos de réis, ou a uma taxa anual acima de $16 \%$, aumentando de cerca de 1,75 para quatro vezes com relação à sua receita. $\mathrm{O}$ aumento foi ainda mais intenso no que tange à dívida externa, a qual, durante essa década, tornou-se quase seis vezes maior, constituindo-se quase $2 / 3$ do total, o que mostra a capacidade limitada

\footnotetext{
A especulação financeira desencadeada, a inflação e os boicotes por meio de "empresas-fantasmas" e ações sem lastro desencadearam, em 1890, grave crise financeira. $\mathrm{O}$ ato de encilhar refere-se às apostas, que eram o modo com que os especuladores atuavam na Bolsa de Valores com as empresas-fantasmas. Essa crise causou o aumento da inflação, recessão, desvalorização cambial e aumento da dívida externa.
} 
de absorção do mercado brasileiro de capitais. Supondo uma taxa média de juros de $5 \%$, o serviço da dívida teria absorvido cerca de um quinto da receita total dos Estados. ${ }^{7}$

Em que pese à opção de buscar a garantia da União (dada pelo aludido decreto de 1890), alguns governos estaduais, ciosos de sua autonomia constitucional como entes federados, tomaram a iniciativa de entabular negociaçōes diretas com banqueiros estrangeiros, mesmo se sujeitando a custos elevados. A exigência de submeter seus pleitos de financiamento externo e suas contas ao Ministério da Fazenda desestimulavam os acordos com o governo federal. Esse foi o caso do Estado do Espírito Santo, o primeiro, na fase republicana, que contratou, em 5 de outubro de 1894, um empréstimo de 17,5 milhões de francos (equivalente a $£ 700.000$ ), junto ao Banco Nacional Brasileiro, a juros anuais de 5\% e elevado deságio de 30\% (tipo 70), dando por garantia as receitas gerais do estado e destinando o produto líquido do empréstimo à construção do trecho da estrada de ferro Espírito Santo a Minas. Em que pesem as condiçôes onerosas do empréstimo, o produto líquido do mesmo (cerca de 11,6 mil contos de réis) correspondeu a 2,6 vezes o valor total da receita pública estadual arrecadada e a 40,6\% do total das exportações do Estado no ano de 1894, representando, sem dúvida, uma soma extremamente elevada.

Conforme afirma o próprio então presidente (governador) do Estado do Espirito Santo, José de Mello Carvalho Moniz Freire (1894, 10):

Antes de um mez da remessa dos papeis para Europa, chegava a proposta dos banqueiros, acompanhada da confirmação de que o emprestimo era de primeira ordem. Pareceram, entretanto, a mim quanto ao Sr. Conde [Francisco] de Figueiredo, desvantajosas as condições da proposta, e diversos telegrammas foram trocados neste sentido, sem resultado, salvo quanto aos detalhes. Não podendo vencer a obstinação e devendo resolver o caso, decidi-me em 21 de setembro a autorizar a operação, contrahindo o emprestimo de setecentas mil libras ao typo de $70 \%$, juros de $5 \%, 1 \%$ de amortisação, a começar de 1896, resgatavel portanto em 33 anos por sorteio ou compra no mercado. Sei perfeitamente que não fiz uma operação financeira de primeira ordem, nem jamais esperei obte-lo; mas tenho profunda certeza de que consegui o mais do que era possível. A primeira difficuldade para o Espirito Santo, que só agora começa a ser devidamente considerado no seio do próprio paiz, era abrir passagem ao seu credito em mercados europeus, e levantar dinheiro sem offerecer nenhuma outra garantia além de seus recursos orçamentarios, e a capacidade de seus homens publicos $[$ sic $] .{ }^{8}$

7 Para uma análise pormenorizada da evolução das finanças brasileiras desde meados do século 19 até a metade dos anos 1980, consultar GOLDSMITH, Raymond W. Brasil 1850-1984: Desenvolvimento Financeiro sob um Século de Inflação. São Paulo: Editora Harper \& Row do Brasil Ltda, 1986. p. 120-145.

8 A citação acima está conforme o texto original contido na Mensagem do Sr. Presidente José de Mello Carvalho Moniz Freire na installação do Congresso legislativo, 1894. Victoria, Typografia do Estado do Espírito Santo, 1894. A gestão de Moniz Freire na governadoria foi de 3 de maio de 1892 a 23 de maio de 1896, ao passo que 
O segundo governo estadual a captar empréstimo externo foi Minas Gerais, que contratou, em 12 de outubro de 1896, a soma de 65 milhôes de francos (68,8 mil contos de réis) junto ao Banque de Paris et des Pays Bas. O valor líquido do empréstimo (cerca de 53,6 mil contos de réis) correspondeu a 2,8 vezes o valor da receita estadual arrecadada durante o ano. Antes dessa operação, o estado tentara todas as formas de captação de recursos no mercado interno de capitais, a exemplo das onerosas antecipaçōes de receita (ARO) junto ao Banco do Brasil e a emissão de títulos do Tesouro com desconto de $7 \%$ ao ano. Em que pese ao deságio de $22 \%$ sobre o valor de face dos títulos dados em garantia aos credores estrangeiros, a taxa de juros mais baixa e o longo prazo da operação (33 anos) eram atrativos que o limitado mercado de capitais interno não podia oferecer.

Conforme exposição de motivos do próprio presidente de Minas, Chrispim Jacques Bias Fortes $(1897,29)$ :

Auctorizado pela lei n. 187, de 12 de outubro do anno passado, contractou o meu governo o lançamento de um emprestimo externo com o Banque de Paris et des Pays-Bas, de Paris, cujo producto satisfizesse os compromissos contrahidos com as empresas de estradas de ferro e realizasse outros emprehendimentos encetados e que não podiam ser interrompidos. Esse importante estabelecimento de credito encarregou-se do lançamento do emprestimo nas praças europeias, mediante commissão de $8 \%$ para todas as despesas [sic]. ${ }^{9}$

O terceiro estado a acessar o mercado externo de capitais no início da fase republicana foi o então mais próspero e desenvolvido: São Paulo, onde se concentrava a maior parte da produção e exportação do café. Em 28 de abril de 1899, o governo paulista firmou empréstimo de $£ 1,0$ milhão (equivalente a 32,2 mil contos de réis) com o banco anglo-alemão J.Henry Schroder Banking Corporation. O objetivo da operação era efetuar resgate de letras de empréstimos anteriores, inclusive o de 1888 , ainda no período imperial. ${ }^{10}$

Este seria o primeiro de uma sequência de empréstimos externos que levaria São Paulo a responder por $46 \%$ do total da dívida externa estadual no final da República Velha. ${ }^{11}$ A ele logo seguiria o empréstimo de 1904, desta vez junto ao Bank of London \& South America, também no valor de $£$ 1,0 milhão, a juros de $5 \%$ ao ano e tipo de $88 \%$ e 10 anos de prazo, no valor bruto de apenas 19,79 mil contos de réis em virtude da forte apreciação ocorrida na taxa do mil réis em face da libra esterlina (38,6\% entre 1899 e 1904), decorrente dos efeitos deflacionários da

o Conde Francisco de Figueiredo (1843-1917) foi ex-diretor do Banco do Brasil e fundador do Banco Nacional do Brazil, subsidiária de bancos franceses.

9 O mandato de Chrispim Fortes foi de 7 de setembro de 1894 a 7 de setembro de 1898 . Os detalhes do empréstimo de 1896 foram expostos na Mensagem do Presidente ao Congresso Mineiro de 1897, p. 29-30.

10 Conforme mensagem do presidente do estado Fernando Prestes de Albuquerque à Assembleia Legislativa a 7 de abril de 1900 .

11 Ver, a propósito do endividamento paulista, o livro de Bouças (1955, 24). 
política econômica e financeira conservadora do ex-ministro da Fazenda Joaquim Murtinho no governo Campos Sales (1898-1902).

A partir do Convênio de Taubaté (firmado em 26 de fevereiro de 1906 pelos estados de São Paulo, Minas Gerais e Rio de Janeiro), teve início a política de valorização dos preços do café nos mercados mundiais mediante a compra de excedentes e estocagem de grandes volumes do produto em recintos alfandegários no exterior. Era uma tentativa de salvaguardar a renda do setor produtor e exportador do café diante da superprodução. Para executar a política (que só depois contou com o apoio do governo federal), o Estado de São Paulo captou um empréstimo emergencial (prazo de um ano) de $£ 1,0$ milhão junto ao banco alemão Diskonto Gesellschaft-Nordeutsche Bank de Berlim, logo seguido por outro, muito maior, de $£ 3$ milhões junto ao banco anglo-alemão J.Henry Schroder Banking Corporation.

A propósito da relativa facilidade de São Paulo contratar volumes cada vez maiores de empréstimos externos, cabe mencionar as intensas relações de negócios entre grandes casas exportadoras de café de origem estrangeira e bancos europeus que financiavam as atividades de comércio exterior dessas empresas. Sobre esse aspecto, Warren Dean $(1991,63)$ destaca:

Ansiosos por apoiar projetos de obras públicas de todo gênero, os governos federal e estadual fomentaram a penetração de firmas européias. Empréstimos contraídos na Europa colocaram São Paulo sob a tutela financeira dos Rothschilds de Paris antes do início do século. A valorização da safra de café de 1906 aumentou os interesses do grupo anglo-alemão Schroeder e do Diskonto Gesellschaft-Nordeutsche Bank, ambos já representados por conexões comerciais e bancárias. ${ }^{12}$

No cômputo geral, desde 1894 até às vésperas da Primeira Guerra Mundial (1913), que provocou retração ou mesmo paralisia nos mercados de capitais europeus para a América do Sul, sucederam-se pelo menos 31 operações de crédito externo firmadas por estados de todas as regiōes do País, totalizando 43,734 milhōes de libras esterlinas, sendo 585,6 milhōes denominados em francos franceses (15 empréstimos, equivalentes a 23,424 milhões de libras) e 20,31 milhōes de libras (16 empréstimos) (ver Quadro 1 a seguir). Com relação à fonte dos recursos, bancos franceses responderam por $53,5 \%$ do valor dos créditos, seguidos pelos ingleses, com $35,5 \%$ do total, e, finalmente, os bancos alemães, com $11 \%$ do total. ${ }^{13}$

12 Para uma análise aprofundada sobre as origens e o processo de desenvolvimento industrial no Estado de São Paulo e o papel do capital estrangeiro, vale a pena consultar Dean (1991).

13 Além dessas 31 operações, há relatos de outros empréstimos tomados por estados, no período 1894-1913, na qualidade de garantidores de órgãos ou bancos estaduais. No entanto, a escassez e/ou contradiçōes nas informaçōes impediram sua contabilização neste trabalho. No mesmo período, cabe mencionar que os municípios das capitais brasileiras também se empenharam em captar diretamente empréstimos externos para financiar seus projetos de desenvolvimento urbano e de saneamento, a começar por Belém, Belo Horizonte e Salvador (1905), seguidas por Manaus (1906), São Paulo (1908), Porto Alegre (1909) e Recife (1910) etc. Para mais informaçōes relativas a valores, condições, garantias e destinação, consultar Bouças (1955, 535-562). 
Quadro 1. Paradiplomacia financeira no Brasil: empréstimos externos dos estados, 1894-1913.

\begin{tabular}{|c|c|c|c|}
\hline Estado & Data & $\begin{array}{l}\text { Valor do } \\
\text { empréstimo }\end{array}$ & Fonte do empréstimo \\
\hline 1. Espírito Santo & $5 / 10 / 1894$ & Frs 17,5 milhōes & Banco Nacional Brasileiro \\
\hline 2. Minas Gerais & $12 / 10 / 1896$ & Frs 65,0 milhōes & Banque de Paris et des Pays Bas \\
\hline 3. São Paulo & $18 / 4 / 1899$ & $£ 1,0$ milhão & Seligman Brothers Ltd \\
\hline 4. Pará & $11 / 12 / 1901$ & $£ 1,45$ milhão & Seligman Brothers Ltd \\
\hline 5. São Paulo & $3 / 12 / 1904$ & $£ 1,0$ milhão & Bank of London \& South America \\
\hline 6. Bahia & $21 / 12 / 1904$ & $£ 1,06$ milhão & Bank of London \& South America \\
\hline 7. Pernambuco & $11 / 3 / 1905$ & $£ 1,0$ milhão & Bemberg \& Cie e H. Legru \\
\hline 8. São Paulo & $4 / 4 / 1905$ & $£ 3,8$ milhões & Dresdner Bank, of Berlin \\
\hline 9. Paraná & 1905 & Frs 20,0 milhões & $\begin{array}{l}\text { Banque Privée de Lyon Marseille e } \\
\text { Comptoir National d'Escompte }\end{array}$ \\
\hline 10. Amazonas & $23 / 5 / 1906$ & Frs 84,0 milhōes & $\begin{array}{l}\text { Société Marseillaise de Crédit Industriel } \\
\text { \& Commercial et de Depôts }\end{array}$ \\
\hline 11. Alagoas & $10 / 8 / 1906$ & Frs 12,5 milhōes & Credit Départemental \\
\hline 12. São Paulo & 1906 & $£ 1,0$ milhão & $\begin{array}{l}\text { Diskonto Gesellschaft-Nordeutsche } \\
\text { Bank of Berlin }\end{array}$ \\
\hline 13. São Paulo & 1906 & $£ 3,0$ milhões & J.Henry Schroder Banking Corporation \\
\hline 14. Pará & $4 / 3 / 1907$ & $£ 650$ mil & Seligman Brothers Ltd \\
\hline 15. São Paulo & 21/10/1907 & $£ 2,0$ milhōes & Sorocabana Railway Company \\
\hline 16. Minas Gerais & 1907 & Frs 25,0 milhōes & Joseph Loste \& Cie \\
\hline 17. Espírito Santo & $13 / 4 / 1908$ & Frs 30,0 milhões & Ch. Victor \& Cie., de Paris \\
\hline 18. Alagoas & 8/1/1909 & $£ 280$ mil & Investment Registry \\
\hline 19. Ceará & $1 / 5 / 1909$ & Frs 15,0 milhōes & Louis Dreyfus \& Cie, of Paris \\
\hline 20. Pernambuco & $7 / 6 / 1909$ & Frs 37,5 milhões & Banque Privée Lyon Marseille \\
\hline 21. Santa Catarina & 4/11/1909 & $£ 250 \mathrm{mil}$ & Erlangers \& Co, e Dunn, Fisher \& Co \\
\hline 22. Bahia & $22 / 1 / 1910$ & Frs 45,0 milhões & $\begin{array}{l}\text { Credit Mobilier Français (Banque } \\
\text { Union Parisienne) }\end{array}$ \\
\hline 23. Rio Grande do Norte & $1 / 3 / 1910$ & Frs 8,75 milhões & Banque Syndicale Française \\
\hline 24. Maranhão & $2 / 11 / 1910$ & Frs 20,0 milhões & Banque Argentine \& Française \\
\hline 25. Minas Gerais & 2/11/1910 & Frs 120,0 milhões & Perier \& Co \\
\hline 26. Pará & 1910 & $£ 200$ mil & Seligman Brothers Ltd \\
\hline 27. Minas Gerais & $27 / 3 / 1911$ & Frs 50,0 milhões & Perier \& Co \\
\hline 28. Paraná & 20/12/1912 & Frs 35,35 milhōes & $\begin{array}{l}\text { Ethelburga Syndicate Ltd, of London e } \\
\text { Banque Privée Lyon Marseille }\end{array}$ \\
\hline 29. Rio de Janeiro & $26 / 3 / 1905$ & $£ 2,5$ milhões & Boulton \& Cia of London \\
\hline 30. Minas Gerais & $19 / 2 / 1913$ & $£ 120 \mathrm{mil}$ & $\begin{array}{l}\text { Dunn, Fischer \& Co. Trust: The British } \\
\text { \& General Debenture Trust Ltd }\end{array}$ \\
\hline 31. Bahia & $22 / 4 / 1913$ & $£ 1,0$ milhão & Lloyd's Bank Ltd \\
\hline
\end{tabular}

Fonte: Valentim Bouças, Dívida Externa Estadual e Municipal, Ministério da Fazenda (1940; 1942; 1955).

Elaborado pelos autores. 
Em termos de moeda nacional (mil réis), as 31 operações contabilizadas pelos estados brasileiros, no período $1894-1913$, totalizaram a cifra de 732,5 mil contos de réis. Para avaliar a dimensão relativa do total desse saldo acumulado de dívida externa contratada pelos governos estaduais, basta ter em mente que, em 1913, as receitas totais do orçamento da República foram de 654 mil contos de réis e as receitas conjuntas de todos os estados da Federação alcançaram a marca de 270 mil contos de réis. Portanto, os estados brasileiros assumiram, em menos de 20 anos, débitos de origem externa não apenas superiores ao orçamento da União, no último ano da série, como equivalentes a $11 \%$ do Produto Interno Bruto do País naquele ano (ver Quadro 2). ${ }^{14}$

Quadro 2. Paradiplomacia financeira no Brasil: empréstimos externos dos estados, 1894-1913.

\begin{tabular}{|c|c|c|c|}
\hline Estado & Data & $\begin{array}{l}\text { Valor do } \\
\text { empréstimo } \\
\text { (mil réis) }\end{array}$ & Fonte do empréstimo \\
\hline 1. Espírito Santo & $5 / 10 / 1894$ & $16.650: 200$ & Banco Nacional Brasileiro \\
\hline 2. Minas Gerais & $12 / 10 / 1896$ & 68.856 .000 & Banque de Paris et des Pays Bas \\
\hline 3. São Paulo & $18 / 4 / 1899$ & 32.258 .000 & Seligman Brothers Ltd \\
\hline 4. Pará & $11 / 12 / 1901$ & 30.890 .800 & Seligman Brothers Ltd \\
\hline 5. São Paulo & $3 / 12 / 1904$ & 19.794 .000 & Bank of London \& South America \\
\hline 6. Bahia & $21 / 12 / 1904$ & 20.859 .627 & Bank of London \& South America \\
\hline 7. Pernambuco & $11 / 3 / 1905$ & 15.238 .000 & Bemberg \& Cie e H. Legru \\
\hline 8. São Paulo & $4 / 4 / 1905$ & 60.039 .344 & Dresdner Bank, of Berlin \\
\hline 9. Paraná & 1905 & 12.166 .000 & $\begin{array}{l}\text { Banque Privée de Lyon Marseille e } \\
\text { Comptoir National d'Escompte, of Paris }\end{array}$ \\
\hline 10. Amazonas & $23 / 5 / 1906$ & 50.302 .560 & $\begin{array}{l}\text { Société Marseillaise de Crédit Industriel } \\
\text { \& Commercial et de Depôts }\end{array}$ \\
\hline 11. Alagoas & $10 / 8 / 1906$ & 7.485 .500 & Credit Départemental \\
\hline 12. São Paulo & 1906 & 14.971 .000 & $\begin{array}{l}\text { Diskonto Gesellschaft-Nordeutsche } \\
\text { Bank of Berlin }\end{array}$ \\
\hline 13. São Paulo & 1906 & 44.913 .000 & J.Henry Schroder Banking Corporation \\
\hline 14. Pará & $4 / 3 / 1907$ & 10.346 .050 & Seligman Brothers Ltd \\
\hline 15. São Paulo & $21 / 10 / 1907$ & 31.688 .855 & Sorocabana Railway Company \\
\hline 16. Minas Gerais & 1907 & 15.917 .000 & Joseph Loste \& Cie \\
\hline 17. Espírito Santo & $13 / 4 / 1908$ & 19.179 .600 & Ch. Victor \& Cie., de Paris \\
\hline 18. Alagoas & $8 / 1 / 1909$ & 4.475 .240 & Investment Registry \\
\hline
\end{tabular}

14 Segundo afirma Goldsmith $(1986,122)$, as despesas totais do governo federal do Brasil foram de 763 mil contos de réis em 1913, o que equivaleu a 11,5\% do PIB estimado para aquele ano, donde se depreende que o PIB foi de 6.634,78 mil contos de réis. Se relacionarmos o valor total de empréstimos externos contratados pelos Estados no período 1894-1913 com o PIB, encontraremos o valor de 11\%. 


\begin{tabular}{|c|c|c|c|}
\hline Estado & Data & $\begin{array}{l}\text { Valor do } \\
\text { empréstimo } \\
\text { (mil réis) }\end{array}$ & Fonte do empréstimo \\
\hline 19. Pernambuco & $7 / 6 / 1909$ & 23.975 .000 & Banque Privée Lyon Marseille \\
\hline 20. Santa Catarina & $4 / 11 / 1909$ & 3.995 .750 & Erlangers \& Co, e Dunn, Fisher \& Co \\
\hline 21. Bahia & $22 / 1 / 1910$ & 27.000 .000 & $\begin{array}{l}\text { Credit Mobilier Français (Banque } \\
\text { Union Parisienne) }\end{array}$ \\
\hline 22. Rio Grande do Norte & $1 / 3 / 1910$ & 5.224 .450 & Banque Syndicale Française \\
\hline 23. Ceará & $1 / 5 / 1910$ & 8.956 .200 & Louis Dreyfus \& Cie, of Paris \\
\hline 24. Maranhão & 2/11/1910 & 11.941 .600 & Banque Argentine \& Française \\
\hline 25. Minas Gerais & 2/11/1910 & 71.650 .000 & Perier \& Co \\
\hline 26. Pará & 1910. & 2.985 .400 & Seligman Brothers Ltd \\
\hline 27. Minas Gerais & $27 / 3 / 1911$ & 30.058 .000 & Perier \& Co \\
\hline 28. Paraná & 20/12/1912 & 33.000 .000 & $\begin{array}{l}\text { Ethelburga Syndicate Ltd, of London } \\
\text { e Banque Privée Lyon Marseille }\end{array}$ \\
\hline 29. Rio de Janeiro & 1912. & 37.500 .000 & Boulton \& Cia of London \\
\hline 30. Minas Gerais & $19 / 2 / 1913$ & 1.805 .280 & $\begin{array}{l}\text { Dunn, Fischer \& Co. Trust: The British } \\
\text { \& General Debenture Trust Ltd }\end{array}$ \\
\hline 31. Bahia & $22 / 4 / 1913$ & 15.044 .000 & Lloyd's Bank Ltd \\
\hline Total & & 732.516 .256 & \\
\hline
\end{tabular}

Fonte: 1) Valentim, F. Bouças, Finanças do Brasil: Dívida Externa Estadual e Municipal, Rio de Janeiro: Ministério da Fazenda, SCTEEF (1940; 1942; 1955); 2) Mensagens dos Governadores, diversos números. Elaborado pelos autores.

Com relação às condições contratuais, os empréstimos externos tomados pelos estados variavam em função: i) da percepção do risco do mutuário (estados com grande receita cambial na exportação inspiravam menos prêmio de risco do que aqueles com menor dinamismo exportador); ii) do prazo (quanto maior o vencimento maior o deságio sobre o valor de face dos títulos ou menor o tipo da operação); e iii) da qualidade das garantias oferecidas. Dependia também da habilidade e capacidade negocial (e da integridade) dos representantes dos estados frente aos banqueiros, assim como da situação macroeconômica conjuntural do País e das condições vigentes no contexto econômico internacional.

As garantias frequentemente giravam em torno do penhor sobre as receitas gerais ou específicas (em geral do imposto de exportação) do estado, de sobretaxas sobre produtos exportados ou de taxas de serviços de transporte ferroviário, de navegação ou de saneamento (água e esgoto) ou iluminação. Também havia hipotecas sobre bens e patrimônio de empresas estaduais.

No entanto, havia leniência dos administradores estaduais pela causa pública quando negociavam os empréstimos, predominando por vezes a visão de curto prazo de rápido acesso aos recursos sem uma análise detida de custo-benefício, incorrendo-se amiúde em desleixo com os encargos futuros das operações sobre o fluxo de caixa do erário estadual. Conforme bem assinala Bouças (1955, 25): 
A análise dos contratos dos empréstimos [estaduais, grifo nosso] e a do emprego do produto dessas transações revelaram muitas vezes fatos que mostram o descaso de muitos de nossos administradores pela causa pública. Geralmente, as condições dos empréstimos efetuadas eram onerosíssimas, não só pela taxa de juros, pelo tipo em que eram lançadas, pelas comissões distribuídas, como também pela inserção de certas cláusulas nos contratos, muitas das quais vexatórias para os nossos brios.

Com relação à destinação dos empréstimos externos tomados pelos estados no período, três finalidades se destacaram: i) resgatar e/ou consolidar dívidas anteriores; ii) financiar obras públicas de infraestrutura; e iii) bancar açôes de valorização do café. Além dessas, houve casos de cobertura de déficits fiscais e pagamento de despesas de custeio convertidas em dívida flutuante (como atraso em pagamentos ao funcionalismo e empreiteiros de obras). No entanto, houve também casos de flagrante desvio de recursos e mesmo de corrupção velada, uma vez que a obra para a qual o empréstimo se destinava não foi executada no todo ou apenas parcialmente, exigindo um novo empréstimo, anos depois, para sua conclusão.

Diante dessa "enxurrada" de empréstimos externos sem controle pelas autoridades federais e dos rumores de negociatas entre banqueiros, intermediários e políticos estaduais na contratação das operaçōes, algumas vozes influentes passaram a questionar a autonomia dos governos estaduais (e municipais) em captar recursos no exterior. A primeira voz que se levantou contra "esse abuso" da autonomia estadual foi a do deputado Bricio Filho, na Câmara Federal, em 27 de dezembro de 1902, apresentando um projeto de lei que taxativamente o coibia de modo formal. Esse projeto não vingou, uma vez que, um ano mais tarde, conforme atesta a Mensagem Presidencial de 1903 ao Congresso Nacional, o então Presidente Rodrigues Alves (quadriênio 1902-1906) criticava a capacidade dos estados de contraírem créditos no exterior e pedia a intervenção legislativa:

$\mathrm{Na}$ ordem administrativa julgo de meu dever invocar a vossa atenção para a faculdade que se tem arrogado alguns Estados de contrahirem, por sua propria autoridade, emprestimos no exterior. Compreende-se bem quanto, em um momento dado, o uso dessa attribuição, poderá ser prejudicial ao credito do paiz, à regularidade de suas finanças e, até às suas relações internacionais. É prudente que o poder legislativo subordine essas operações a normas que afastem da União compromissos ou embaraços que possam sobrevir. O Congresso não ignora que um paiz, de regimen igual ao nosso, já se viu forçado a prohibir o uso de identica attribuição pelas perturbações que infligia à política internacional e às condições geraes das finanças. ${ }^{15}$

Em que pese a vontade do Presidente da República, os parlamentares não se interessaram em votar contra as prerrogativas de seus estados em contratar

15 Conforme a Mensagem apresentada ao Congresso Nacional na abertura da Primeira Sessão da Quinta Legislatura pelo Presidente da República Francisco de Paula Rodrigues Alves aos 3 de maio de 1903, p. 12. 
diretamente créditos no exterior. Tanto foi assim que o presidente Rodrigues Alves, na Mensagem ao Congresso de 1905, voltou a tratar dos empréstimos de entes subnacionais e instigou os parlamentares a regular a matéria, de modo que "fixem as relaçôes dos Estados com a União sobre serviço tão importante [os empréstimos externos] e que muito póde interessar às finanças da União".

Na sua última Mensagem (a de 1906), o Presidente afirmou com certa fadiga:

Quanto aos emprestimos externos, contrahidos pelos Estados, continúo a pensar que é materia de alta relevancia, que deve ser devidamente ponderada pelo Congresso. É de toda conveniencia que a União seja informada dos recursos que forem destinados à amortização de taes emprestimos, assim como si os Estados estão apparelhados para o pagamento das prestaçōes no tempo proprio. Há, sobretudo, a receiar o perigo de serem incluidos, nos contractos, clausulas que não devam prevalecer por infringirem principios fundamentaes do nosso systema de governo [sic].

A eclosão das guerras balcânicas (1912 e 1913) e depois a Primeira Guerra Mundial e o novo empréstimo de consolidação (funding-loan) do Brasil em 1914 travaram os mercados financeiros europeus, o que fez retrair as captaçôes de dívidas pelos estados. Mesmo assim, o caso voltou à baila em 1912, quando o então senador Sá Freire apresentou projeto de lei que proibia empréstimos estaduais e municipais, impedia a cotação de seus títulos na bolsa de valores sem autorização do Legislativo Federal e determinava a intervenção da União no caso de pressão de credores estrangeiros. No entanto, sua proposta foi barrada sob a alegativa de que "violava as ideias cardeais do regime federativo [sic]".

O então influente político e pensador social brasileiro Alberto Torres se colocou contrário à autonomia dos entes subnacionais em exercitar sua faculdade de contratar empréstimos no exterior, chegando a propor a revisão na Constituição Federal de 1891, incluindo entre os casos de intervenção federal nos Estados o seguinte (Torres 1914, 249):

O caso do parágrafo n. ${ }^{\circ} 12$ representa interesse de tal monta, que só se compreenderia não fosse adotado por inteira escravização da política aos caprichos de campanário. É monstruoso que um país como o Brasil permaneça sujeito à responsabilidade de emprestimos, levantados por Estados e municipalidades, sem fiscalização federal, quando as responsabilidades da União já excedem os limites de licenciosa tolerância, e a administração se mostra cada vez mais anarchizada, em todos os órgãos do poder público [sic].

Apesar do empenho do senador Sá Freire na sua campanha, o Senado não votou a lei que cerceava a liberdade dos estados de captarem recursos no exterior sem autorização da União. Conforme registrado no Diário Oficial da União do dia 22 de novembro de 1918, que tratou do tema da dívida externa brasileira, "o apello do Presidente de 1902-1906 ficou até hoje sem solução parlamentar [sic]". 
O fato é que, a despeito das tentativas de limitar a autonomia dos entes subnacionais de contratar empréstimos externos, o saldo dessa dívida externa subnacional (estados e municípios) teria atingido a marca de $£$ 62,137 milhões, no final de $1914 .{ }^{16}$ Esse valor correspondia a $38,9 \%$ do total da dívida externa brasileira. Após passada a fase de paralisia dos financiamentos internacionais, durante a $1^{\text {a }}$ Guerra Mundial, os estados e municípios continuariam, de 1919 até 1931, exercitando livremente sua paradiplomacia financeira, captando empréstimos diretamente no exterior, sem controle ou interferência da União.

\section{A segunda fase da paradiplomacia financeira, 1914-1930: fontes do crédito externo e sua destinação}

A abundante oferta de capitais europeus de empréstimo e investimento direto que se verificou de 1890 a 1913 começou a escassear com a eclosão de conflitos. Iniciada a Primeira Guerra Mundial (em 28 de julho de 1914), o movimento de capitais travou-se, deixando os tomadores na América Latina sem acesso a créditos de bancos europeus. Conforme registrou o então ministro da Fazenda, Rivadavia Corrêa $(1914,4)$ :

Desde que rebentou o conflicto no oriente da Europa, uma grande e ameaçadora nuvem começou a pairar sobre aquelle continente; e, apesar de, no momento, o conflicto se ter circumscripto aos paizes dos Balkans, parece que em todos os espiritos se gerou a convicção de que a paz européa estava seriamente ameaçada. O menor incidente podia dar causa à conflagração geral, e assim aconteceu com o desenrolar do drama de Sarajevo. A situação de duvida, ou antes, de quasi temor que dominou a Europa, quanto à permanencia e solidez da paz continental, causou grande abalo nos mercados financeiros europeus que veio a se reflectir de modo desastroso nas praças commerciais da America do Sul [sic].

A guerra na Europa, ao provocar a quase estagnação dos negócios e o colapso no financiamento externo, levou não só o governo federal como os governos estaduais no Brasil a sérias dificuldades financeiras para manter com regularidade os serviços de suas dívidas externas, tendo, pois, que negociarem com os credores empréstimos de consolidação (funding-loans). Tais foram os casos do governo federal (outubro de 1914) e dos estados do Amazonas, Bahia e Pará (em 1915), Paraná (em 1916) e Bahia novamente (em 1918). ${ }^{17}$

16 Segundo valor apurado no Annuario Estatístico de Bulhões Carvalho e transcrito do referido texto publicado no Diário Oficial da União, de 22 de novembro de 1918, p. 13.861.

17 Segundo Sandroni $(2005,362)$, o Funding Loan ou empréstimo de consolidação é uma moratória negociada em que os credores concedem a um devedor público (soberano ou ente subnacional) um novo empréstimo correspondente aos encargos da dívida vencida e vincenda. $\mathrm{O}$ termo incorporou-se à História do Brasil, pois esse recurso foi utilizado várias vezes pelos credores do País em momentos de crise de pagamentos externos. 
Somente após o fim da guerra e o Tratado de Versailles (1919) é que os fluxos de financiamentos começaram a se normalizar em direção ao Brasil. Tanto é assim que Rio Grande do Sul e Santa Catarina conseguem contratar, em 1919, operaçôes de créditos para aplicar em obras de infraestrutura. O Espirito Santo, por seu turno, emprega o produto de novo empréstimo externo obtido para encampar um banco hipotecário e agrícola. No entanto, o fato novo é a entrada em cena do primeiro empréstimo norte-americano (US\$ 5 milhões) a estados, no caso Santa Catarina, pelo banco Equitable Trust Company, de Nova Iorque (ver Quadro 3).

Quadro 3. Paradiplomacia financeira no Brasil: empréstimos externos dos estados, 1915-1919.

\begin{tabular}{|l|c|r|l|}
\hline \multicolumn{1}{|c|}{ Estados } & \multicolumn{1}{|c|}{ Data } & \multicolumn{1}{c|}{ Valor } & \multicolumn{1}{c|}{ Destinação } \\
\hline Amazonas & $13 / 12 / 1915$ & Frs 20,5 milhões & Funding-loan \\
Bahia & $29 / 1 / 1915$ & $£ 787.340$ & Funding-loan \\
Pará & $9 / 12 / 1915$ & $£ 1,070$ milhão & Funding-loan \\
Paraná & $20 / 3 / 1916$ & Frs 6,763 milhões & Funding-loan \\
Bahia & $7 / 6 / 1918$ & $£ 333.598$ & Funding-loan \\
Rio G. do Sul & 1919 & Frs 68,32 milhōes & Obras de infraestrutura \\
Espírito Santo & $12 / 7 / 1919$ & Frs 24,960 milhões & Encampação de banco \\
Santa Catarina & $1 / 12 / 1919$ & US $\$ 5,0$ milhões & Obras de infraestrutura \\
\hline
\end{tabular}

Fonte: Valentim, F. Bouças, Finanças do Brasil: Dívida Externa - 1824-1945. Rio de Janeiro: Ministério da Fazenda, SCTEEF, Volume XIX, 1955. Elaborado pelos autores.

Essa investida do capital bancário norte-americano sobre a economia brasileira já refletia o declínio relativo da Grã-Bretanha e a ascensão gradativa dos EUA como potência emergente. O intercâmbio comercial do Brasil com os EUA era crescente, com o país assumindo a posição de maior mercado de destino das exportaçôes brasileiras de café. Conforme citam Cervo e Bueno (2002, 206):

Nessa altura, os Estados Unidos suplantavam a Gră-Bretanha e tornavam-se, simultaneamente, os principais fornecedores e compradores do Brasil. No que se refere a investimentos, cresceu sensivelmente a presença norte-americana na década de 1920. Os 50 milhões de dólares investidos, em 1913, saltaram para 476 milhōes em 1929. O Governo brasileiro, entretanto, ainda recorria aos britânicos na década de 1920. Também em relação aos empréstimos feitos no estrangeiro houve transição da preponderância britânica para a norte-americana na década de 1920. Em 1929, os EUA eram credores de quase um terço da dívida externa brasileira.

Essa fase de captação de empréstimos externos pelos estados brasileiros do pósguerra até 1931 foi a mais intensa, tanto em volume como em valor das operações. Foram 11 estados mutuários e 37 operações de crédito externo no período, 
distribuídas por quatro divisas estrangeiras, totalizando 68,32 milhões de francos franceses (um empréstimo), 18 milhōes de florins holandeses (um empréstimo), 42,784 milhões de libras esterlinas (13 empréstimos) e US\$ 178,06 milhões (22 empréstimos), o que corrobora com a observação anterior sobre a rápida transição da Grã-Bretanha para os EUA como principal provedor de capitais ao Brasil no período pós-Primeira Guerra Mundial (ver Quadro 4).

Quadro 4. Paradiplomacia financeira: empréstimos externos dos estados, 1919-1931.

\begin{tabular}{|c|c|c|c|c|c|c|}
\hline \multirow{2}{*}{ Mutuário } & \multicolumn{5}{|c|}{ Valor do empréstimo } & \multirow{2}{*}{ Data } \\
\hline & No & Francos & Libra & US Dólar & Florim & \\
\hline Bahia & 1 & & 338500 & & & $10 / 1 / 1928$ \\
\hline Ceará & 1 & & & 2.000 .000 & & $1 / 8 / 1922$ \\
\hline \multirow[t]{3}{*}{ Espírito Santo } & 1 & & & 1.750 .000 & & $26 / 10 / 1927$ \\
\hline & 1 & & & 750.000 & & $26 / 3 / 1928$ \\
\hline & 1 & & & 1.170 .000 & & $26 / 3 / 1931$ \\
\hline \multirow[t]{3}{*}{ Maranhão } & 1 & & & 1.500 .000 & & $26 / 3 / 1923$ \\
\hline & 1 & & & 286.000 & & $1 / 4 / 1926$ \\
\hline & 1 & & & 1.750 .000 & & $15 / 3 / 1928$ \\
\hline \multirow[t]{3}{*}{ Minas Gerais } & 1 & & 1.750 .000 & & & $14 / 3 / 1928$ \\
\hline & 1 & & & 8.500 .000 & & $14 / 3 / 1928$ \\
\hline & 1 & & & 8.000 .000 & & $14 / 9 / 1929$ \\
\hline Pará & 1 & & 1.070 .000 & & & $9 / 12 / 1915$ \\
\hline \multirow[t]{2}{*}{ Paraná } & 1 & & 1.000 .000 & & & $19 / 4 / 1928$ \\
\hline & 1 & & & 4.860 .000 & & $19 / 4 / 1928$ \\
\hline Pernambuco & 1 & & & 6.000 .000 & & $10 / 3 / 1927$ \\
\hline \multirow[t]{3}{*}{ Rio de Janeiro } & 1 & & 1.926 .500 & & & $28 / 4 / 1927$ \\
\hline & 1 & & 1.891 .000 & & & 29/4/1927 \\
\hline & 1 & & & 6.000 .000 & & $15 / 5 / 1929$ \\
\hline \multirow{4}{*}{$\begin{array}{l}\text { Rio Grande } \\
\text { do Sul }\end{array}$} & 1 & 68.320 .000 & & & & 29/9/1919 \\
\hline & 1 & & & 10.000 .000 & & $18 / 11 / 1921$ \\
\hline & 1 & & & 10.000 .000 & & 13/1/1927 \\
\hline & 1 & & & 23.000 .000 & & $6 / 7 / 1928$ \\
\hline \multirow[t]{3}{*}{ Santa Catarina } & 1 & & 250.000 & & & 4/11/1909 \\
\hline & 1 & & & 5.000 .000 & & $1 / 12 / 1919$ \\
\hline & 1 & & & 5.000 .000 & & $14 / 7 / 1922$ \\
\hline
\end{tabular}




\begin{tabular}{|c|c|c|c|c|c|c|}
\hline \multirow{2}{*}{ Mutuário } & \multicolumn{5}{|c|}{ Valor do empréstimo } & \multirow{2}{*}{ Data } \\
\hline & No & Francos & Libra & US Dólar & Florim & \\
\hline \multirow[t]{12}{*}{ São Paulo } & 1 & & 2.000 .000 & & & $8 / 3 / 1921$ \\
\hline & 1 & & & & 18.000 .000 & $9 / 3 / 1921$ \\
\hline & 1 & & & 10.000 .000 & & $14 / 3 / 1921$ \\
\hline & 1 & & & 15.000 .000 & & $9 / 10 / 1925$ \\
\hline & 1 & & 10.000 .000 & & & $2 / 1 / 1926$ \\
\hline & 1 & & & 7.500 .000 & & $18 / 3 / 1926$ \\
\hline & 1 & & 2.500 .000 & & & $19 / 3 / 1926$ \\
\hline & 1 & & 3.750 .000 & & & $22 / 11 / 1927$ \\
\hline & 1 & & 3.500 .000 & & & 19/7/1928 \\
\hline & 1 & & & 15.000 .000 & & $19 / 7 / 1928$ \\
\hline & 1 & & 12.808 .000 & & & $24 / 4 / 1930$ \\
\hline & 1 & & & 35.000 .000 & & $24 / 4 / 1930$ \\
\hline Total geral: & 37 & 68.320 .000 & 42.784 .000 & 178.066 .000 & 18.000 .000 & \\
\hline
\end{tabular}

Fonte: 1) Valentim Bouças, Dívida Externa Estadual e Municipal, Ministério da Fazenda (1940; 1942; 1955); 2) Mensagens dos Governadores, diversos números. Elaborado pelos autores.

Ao expressar o montante dos empréstimos em termos da moeda nacional, verifica-se que os 11 estados supramencionados foram responsáveis por um valor total de dívidas de 3.040.647.523\$000 (três milhôes e quarenta mil seiscentos e quarenta e sete contos e quinhentos e vinte e três mil réis). O Quadro 5 contém, além do registro do valor dos empréstimos por mutuário (estados) em mil réis, a fonte (banco estrangeiro provedor de crédito) e a respectiva destinação dos recursos. 


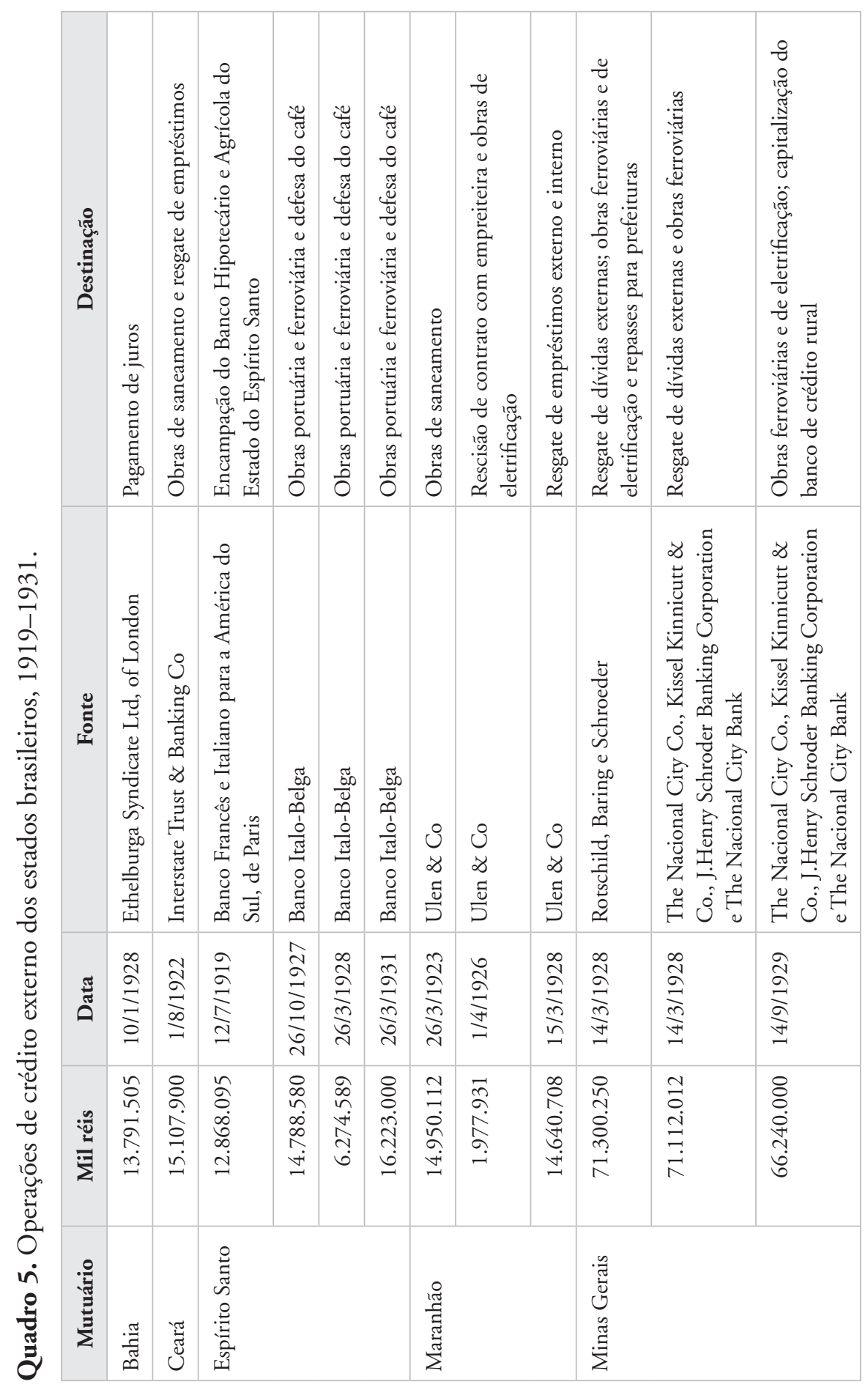




\begin{tabular}{|c|c|c|c|c|c|c|c|c|c|c|c|c|}
\hline 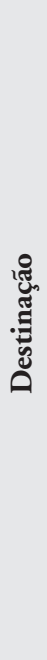 & 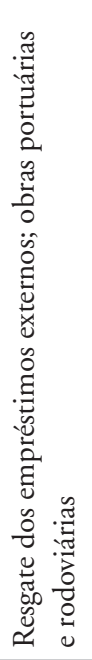 & 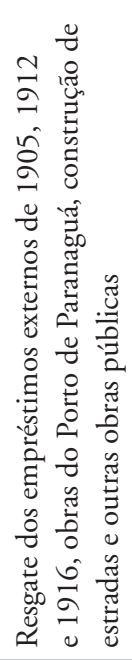 & 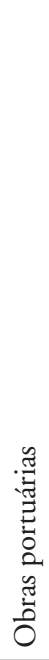 & 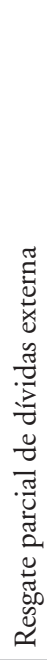 & 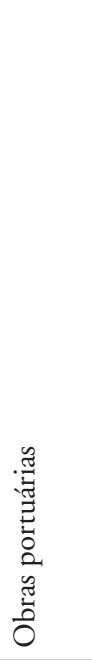 & 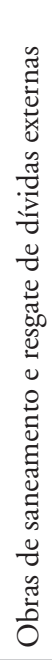 & 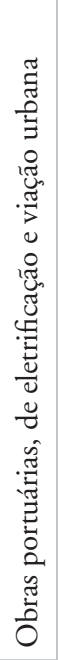 & 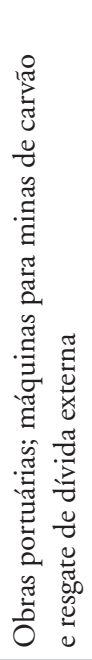 & 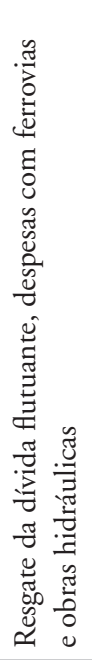 & 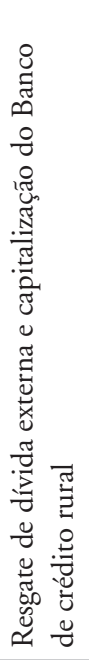 & 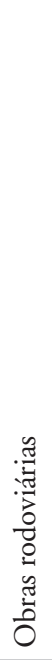 & 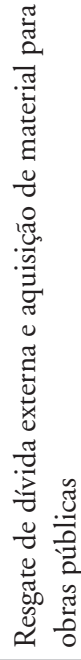 \\
\hline 节 & 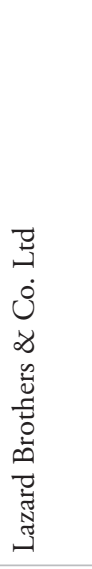 & 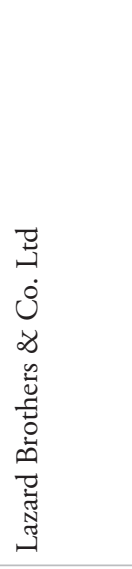 & 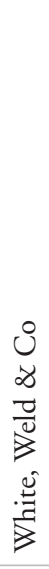 & 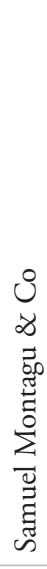 & 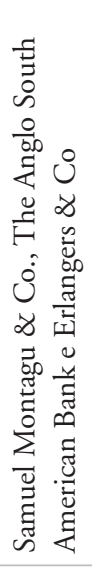 & 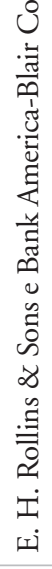 & 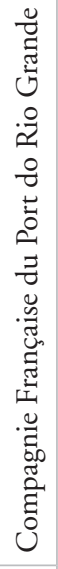 & 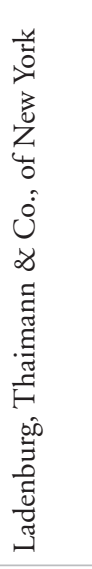 & 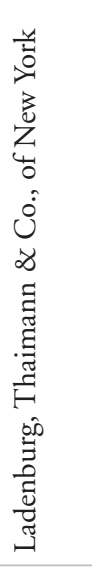 & 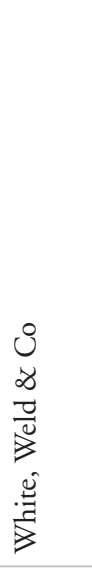 & 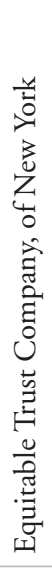 & 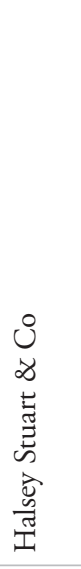 \\
\hline ڤี & $\frac{\stackrel{\infty}{\stackrel{亠}{\leftrightarrows}}}{\stackrel{亠}{\leftrightarrows}}$ & 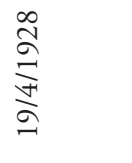 & $\frac{\hat{\curvearrowright}}{\stackrel{\sigma}{a}}$ & 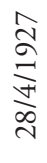 & $\frac{\widehat{\widehat{े}}}{\stackrel{Ð}{\grave{े}}}$ & $\frac{\grave{2}}{\frac{2}{n}}$ & $\frac{\stackrel{a}{a}}{\frac{\grave{a}}{a}}$ & 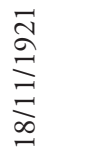 & 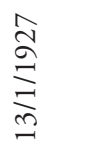 & $\frac{\stackrel{\infty}{N}}{\stackrel{N}{\sigma}}$ & $\underset{ٍ}{\stackrel{a}{ٍ}}$ & 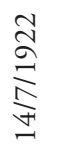 \\
\hline$\sum^{2}$ & $\begin{array}{l}8 \\
0 \\
\stackrel{\leftrightarrow}{+} \\
\stackrel{+}{1} \\
\stackrel{+}{+1}\end{array}$ & 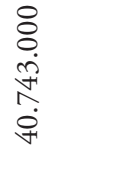 & 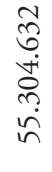 & 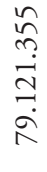 & 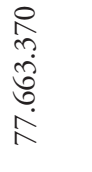 & 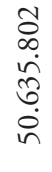 & 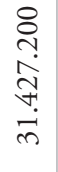 & 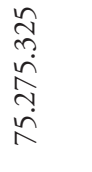 & 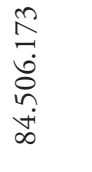 & 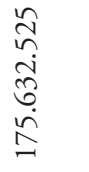 & 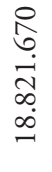 & 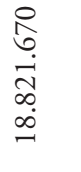 \\
\hline 䓠 &  & & 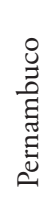 & 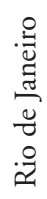 & & & \multicolumn{4}{|c|}{ 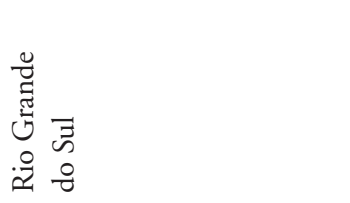 } & \multicolumn{2}{|l|}{ 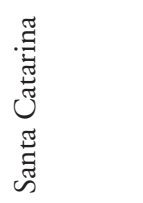 } \\
\hline
\end{tabular}




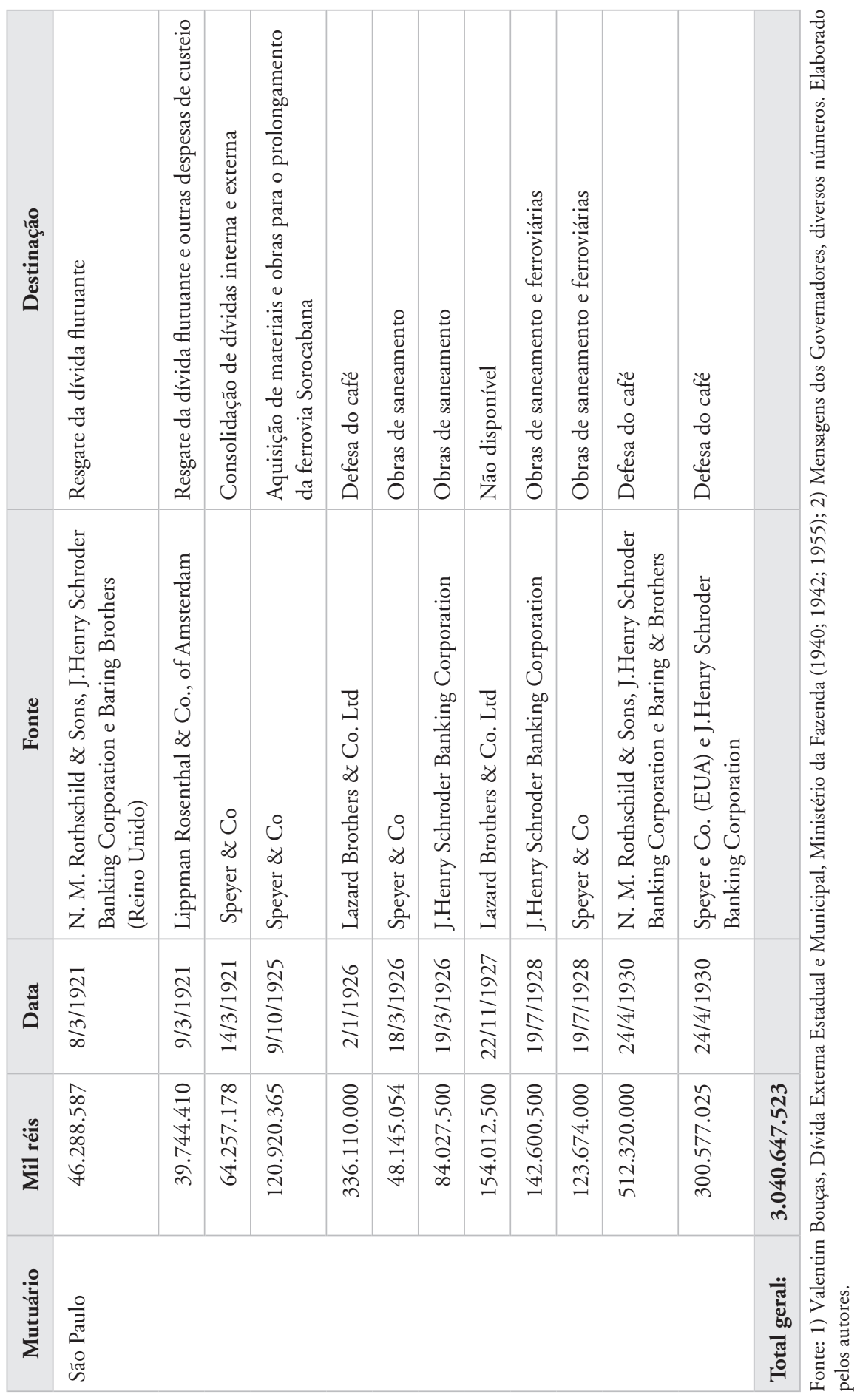


Dessa elevada soma de três milhões e quarenta mil réis, feitos os descontos de praxe (deságio sobre o valor de face e outros encargos, algo em torno de 15\%), o produto líquido dos empréstimos rendeu para os cofres estaduais 2,584,5 milhōes de contos de réis, o que representou $21,5 \%$ do total das receitas orçamentárias arrecadadas por todos os estados no período 1919-1931 (ver Quadro 6).

Quadro 6. Estados brasileiros: receita, despesa e captação de empréstimos externos, 1919-1931.

\begin{tabular}{|c|c|c|c|c|}
\hline Exercício & $\begin{array}{c}\text { Receita } \\
\text { arrecadada }\end{array}$ & $\begin{array}{c}\text { Despesa realizada } \\
\text { Contos de réis } \\
\mathbf{( 1 : 0 0 0 \$ 0 0 0 )}\end{array}$ & $\begin{array}{c}\text { Superávit(+) } \\
\text { ou Déficit(-) }\end{array}$ & $\begin{array}{r}\text { Receita líquida } \\
\text { dos empréstimos } \\
\text { externos dos estados }\end{array}$ \\
\hline 1919 & 396.994 & 401.909 & -4.915 & 53.649 \\
1920 & 489.923 & 505.941 & -16.018 & 0 \\
1921 & 497.799 & 530.760 & -32.961 & 191.732 \\
1922 & 534.738 & 613.513 & -78.775 & 28.840 \\
1923 & 713.765 & 800.441 & -86.676 & 12.708 \\
1924 & 864.920 & 882.879 & -17.959 & 0 \\
1925 & 1.068 .408 & 1.116 .123 & -47.715 & 102.782 \\
1926 & 1.032 .538 & 1.273 .391 & -240.853 & 399.721 \\
1927 & 1.170 .273 & 1.460 .558 & -290.285 & 395.587 \\
1928 & 1.270 .970 & 1.507 .625 & -236.655 & 595.435 \\
1929 & 1.441 .032 & 1.782 .316 & -341.284 & 99.344 \\
1930 & 1.211 .825 & 1.716 .780 & -504.955 & 690.962 \\
1931 & 1.337 .523 & 1.704 .480 & -366.957 & 13.790 \\
\hline Valor acumulado & 12.030 .708 & 14.296 .716 & -2.266 .008 & 2.584 .551 \\
\hline em 1913-1931 & & & & \\
\hline
\end{tabular}

Fonte: 1) Anuário Estatístico do Brasil 1947. Rio de Janeiro: IBGE, v. 8, 1948; 2) Valentim Bouças, Dívida Externa Estadual e Municipal, Ministério da Fazenda (1940; 1942; 1955). Elaborado pelos autores.

Vale assinalar que o valor líquido dos empréstimos (cerca de 2,584 milhões de contos de réis), no período, também superou com ampla margem o saldo acumulado dos déficits fiscais dos estados no período, que alcançou 2,266 milhões de contos de réis, o que implica afirmar que, sem os empréstimos externos, os estados brasileiros não poderiam ter conseguido financiar seus déficits fiscais, nem investir em obras de infraestrutura (portuária, rodoviária, ferroviária e saneamento urbano). Além do mais, expressiva parte dos recursos captados foram utilizados para resgatar débitos pendentes, capitalizar bancos rurais, repassar verbas a municípios, cobrir gastos correntes e financiar onerosos e "duvidosos" programas de valorização dos preços do café nos mercados internacionais, ação sobretudo levada a cabo pelo Estado de São Paulo entre 1906-1931.

Em termos de distribuição geográfica da paradiplomacia financeira, predominaram estados das áreas mais ricas do País (São Paulo, Minas Gerais, Rio de Janeiro, Rio Grande do Sul e Paraná), mas com expressiva presença dos estados 
mais atrasados do Nordeste: Bahia, Ceará, Pernambuco e Maranhão. Do Norte do País, nem mesmo o Pará, que figurou dentre os captadores de recursos externos no período anterior (1894-1913), voltou a acessar o mercado externo de capitais após o empréstimo de consolidação em 1915. A decadência das exportações de borracha e o default do estado após 1915 explicam a falta de acesso ao crédito externo. Por outro lado, a concentração dos empréstimos no Estado de São Paulo é notória: $64,8 \%$ do valor total das operaçóes de crédito externo dos estados brasileiros, no período 1919-1931, cabendo aos três seguintes combinados (Rio Grande do Sul, Minas Gerais e Rio de Janeiro) mais de um quarto $(25,7 \%)$ do valor total (ver Quadro 7).

Quadro 7. Paradiplomacia Financeira no Brasil: captação externa pelos estados, 1919-1931.

\begin{tabular}{|l|c|c|}
\hline \multicolumn{1}{|c|}{ Estados } & Valor dos empréstimos (em contos de réis) & Participação (\%) \\
\hline São Paulo & $1.972 .677,12$ & 64,88 \\
Rio Grande do Sul & $366.841,22$ & 12,06 \\
Minas Gerais & $208.652,26$ & 6,86 \\
Rio de Janeiro & $207.420,53$ & 6,82 \\
Paraná & $81.486,00$ & 2,68 \\
Pernambuco & $55.304,63$ & 1,82 \\
Santa Catarina & $37.643,34$ & 1,24 \\
Espírito Santo & $50.154,26$ & 1,65 \\
Maranhão & $31.568,75$ & 1,04 \\
Ceará & $15.107,90$ & 0,50 \\
Bahia & $13.791,51$ & 0,45 \\
\hline Total & $\mathbf{3 . 0 4 0 . 6 4 7 , 5 2}$ & $\mathbf{1 0 0 , 0 0}$ \\
\hline
\end{tabular}

Fonte: Valentim Bouças, Dívida Externa Estadual e Municipal, Ministério da Fazenda (1940; 1942; 1955). Elaborado pelos autores.

Essa concentração de empréstimos externos em poucos estados no período refletiu, em grande medida, a capacidade de endividamento diferenciada dos estados que exportavam produtos de ampla aceitação nos mercados externos, isto é, café e borracha. Tanto foi assim que há evidências que indicam que os estados mais ricos do Brasil (então os maiores exportadores de commodities) se beneficiavam de custos menores de capital (juros efetivos menores), ao passo que os estados mais pobres incorriam em custos maiores nos empréstimos externos em função de uma percepção de risco maior para os credores. A propósito, Fritscher e Musacchio $(2009,26)$ afirmam:

The results of our study show that the cost of capital for Brazilian states and the probability of issuing state debt in international capital markets were highly correlated with state revenues per capita. Our argument is that revenues 
per capita are highly correlated with exports per capita by state and that the level of exports per capita actually depended on the kind of commodities each state was able to export between 1890 and $1930 .^{18}$

\section{Crise de endividamento e exaustão da paradiplomacia financeira no fim da República Velha}

A debacle da economia cafeeira, desencadeada pela crise econômica mundial de 1929 , e a Revolução de 1930 inauguraram nova etapa, abrindo espaços às alterações nas relaçôes intergovernamentais e no reordenamento institucional do País. A superprodução do café, aliada à Grande Depressão, gerada a partir do crash da Bolsa de Nova Iorque em 1929, reduziram o valor exportado e, por conseguinte, a arrecadação estadual, levando à inadimplência generalizada no serviço da dívida externa dos governos subnacionais brasileiros. A crise alcançou tal dimensão que não poderia mais ser resolvida no âmbito dos estados. As elites regionais, comprometidas financeiramente, perderam o poder de administrá-la e abriram espaço à ação federal.

O governo central, sob a liderança de Vargas, a partir de 1930, passou então a gerir a crise, atuando com certa autonomia em relação aos interesses locais e regionais. Definiu-se nova fase na formação do Estado brasileiro, com a centralização do poder e a constituição de um aparelho estatal com maior poder de regulação e controle sobre diversos interesses específicos, transformando-os em problemas nacionais e sujeitos à definição de políticas de Estado. Conforme assinala Lopreato $(2000,3)$ :

A crise criou as condiçôes, no plano econômico e político, para a ampliação e diversificação dos órgãos regulatórios federais. O governo central incorporou os órgãos estaduais do café e do açúcar encarregados da política de valorização de preços e criou outros institutos semelhantes (sal, mate, cacau e pinho), bem como estendeu sua atuação implantando os Ministérios do Trabalho, Indústria e Comércio e da Educação e Saúde Pública. Ampliou os espaços de definição da política econômica estruturando órgãos responsáveis pela ação nas áreas de comércio exterior, monetária e creditícia, câmbio e seguros, bem como a criação de comissões executivas e empresas estatais com atuação na política industrial.

O fato é que, com a Revolução de 1930 e o colapso do financiamento externo, causado pelos efeitos da Grande Depressão, o novo governo provisório decretou a moratória da dívida externa da União, estados e municípios. Feito isso, a primeira

18 A associação entre as exportações e as receitas dos governos estaduais, no período 1891-1930, é relevante no caso brasileiro devido à forma extremada de federalismo fiscal que o governo republicano brasileiro aprovou na Constituição de 1891, uma vez que concedeu aos governos estaduais a competência de arrecadar o imposto sobre as exportaçôes. 
providência de seu ministro da Fazenda, José Maria Whitaker, foi levantar a verdadeira situação de cada ente da federação com relação às suas dívidas externas. A centralização do poder no governo federal - que então nomeara interventores para os governos estaduais - permitiu, pela primeira vez, o acesso pleno do Ministério da Fazenda a informações fidedignas sobre contratos de empréstimos e a situação dos serviços das dívidas de todos os estados, antes sonegadas pelos governadores, ciosos de sua autonomia federativa.

O resultado da sindicância foi desalentador, conforme testemunha ocular no processo de investigação, Valentim Bouças (1891-1964), ex-secretário técnico da Comissão de Estudos Técnicos de Economia e Finanças do Ministério da Fazenda, ex-negociador da dívida externa brasileira e membro da delegação brasileira na Conferência de Bretton Woods (Bouças 1955, 23-24):

Em 31 de dezembro de 1930, a dívida externa dos 15 Estados que têm empréstimos realizados no exterior, era representado por $£ 86.214 .000$. Essa dívida exige, anualmente, de acordo com os respectivos contratos, para o seu serviço, a remessa de $£ 7.386 .000$. Feita a conversão, a dívida externa consolidada dos Estados é de 3.448.560 contos de réis, sendo os seus encargos anuais de 295.440 contos de réis. Apenas cinco Estados não têm dívida consolidada externa e são eles em ordem geográfica: Piauí, Paraíba, Sergipe, Goiás e Mato Grosso. A dívida externa [estadual] é três vezes a receita estimada e o serviço anual, de acôrdo com os contratos, exige $25 \%$ da receita total. Dos Estados, o que mais deve no exterior, em números absolutos, é São Paulo; e o Rio Grande do Norte é o que tem a menor dívida externa. ${ }^{19}$

A análise dos contratos de empréstimos e da destinação da receita dessas operações revelaram amiúde o descaso de muitos dos governadores pela coisa pública durante a República Velha. Em geral, as condições dos empréstimos efetuados eram muito onerosas, não só pela taxa de juros, mas pelo elevado deságio em que eram lançados, pelas comissões pagas, como também pela inserção de cláusulas contratuais que feriam a legislação federal. Em muitos casos, houve claro desvio na aplicação de recursos com o endividamento legalmente autorizado para obras públicas utilizado na prática para financiar déficits, pagar folha de servidores públicos e cobrir dívida flutuante em vez de financiar investimentos.

Por conta desses "descalabros" nas dívidas estaduais, o governo brasileiro, a partir da Constituição de 1934, suspendeu a descentralização fiscal imperante na República Velha, instituindo novo sistema tributário e de repartição de receitas, retirando dos estados os direitos de taxarem seus produtos de exportação e de contrair livremente empréstimos no exterior, pondo fim à primeira experiência de paradiplomacia financeira no País, a qual durara por quase 40 anos. Por seu

19 Ainda segundo Bouças (1955), a situação de inadimplência estadual para com a dívida externa era generalizada entre os estados brasileiros. Mesmo São Paulo, o estado mais rico da federação, tinha que alocar para o serviço da dívida quase $49 \%$ de sua receita total no ano de 1932. 
turno, essa proibição de governos estaduais captarem diretamente empréstimos no exterior haveria de perdurar por quase duas décadas, somente voltando a ser permitida a contratação de empréstimos externos pelos estados em finais dos anos 1940 e início dos anos 1950.

\section{Conclusões}

O resgate de 40 anos de paradiplomacia financeira no Brasil durante a República Velha revelou que a busca da captação de recursos externos pelos estados resultou de duas tendências, uma de natureza interna e outra externa: i) a descentralização política e administrativa trazida pela primeira constituição republicana e federativa após o fim do regime monárquico, e ii) a mundialização das finanças no final do século 19, que abriu espaço para o acesso ampliado de países da periferia aos capitais externos. Esses dois fatores influenciaram conjuntamente os entes subnacionais na busca de recursos fora do território nacional, o que contribuiu para convertê-los em prematuros atores coadjuvantes no cenário internacional.

Assim, o conceito moderno e atual de paradiplomacia pode ser empregado para explicar o processo precoce de extroversão dos governos estaduais brasileiros na busca de captar recursos externos para cobrir suas necessidades de financiamento. A forte descentralização federativa que caracterizou o sistema político brasileiro nos primórdios do regime republicano permitiu não só livre acesso dos estados aos créditos internacionais, como ensejou um descontrole que acabou por gerar uma crise de endividamento e exaustão do crédito externo. A crise econômica de 1929 (um elemento do sistema internacional) e a Revolução de 1930 no País (um fator de política doméstica) puseram fim a essa fase incipiente da paradiplomacia financeira no País.

\section{Referências bibliográficas}

ABREU, Marcelo de Paiva. “Os Funding Loans Brasileiros, 1898-1931”, Rio de Janeiro, PUC, 2002. BOUÇAS, Valentim. Finanças do Brasil: divida externa - 1824-1945. Rio de Janeiro: Ministério da Fazenda, Secretaria do Conselho Técnico de Economia e Finanças, Volume XIX, 1955.

CERVO, Amado Cervo e BUENO, Clodoaldo. História da Política Exterior do Brasil. Brasília; Editora Universidade de Brasília, 2011.

DEAN, Warren. A Industrialização de São Paulo. Rio de Janeiro: Editora Bertrand Brasil S.A, 1991.

DEL PRIORE, Mary e VENÂNCIO, Renato Pinto. O Livro de Ouro da História do Brasil. Rio de Janeiro: Ediouro, 2001.

DUCHACEK, Ivo. "Perforated Sovereignties: Towards a Typology of New Actors in International Relations", In: Federalism and International Relations: the role of subnational units / Ed: Hans MICHELMANN e Panayotis SOLDATOS. Oxford: Claredon Press, 1990. 
FAUSTO, Boris. A Revolução de 30: Historiografia e História. São Paulo: Companhia das Letras, 1997.

FILOMENO, Filipe Amin. "A crise Baring e a crise do Encilhamento nos quadros da economiamundo capitalista”. In: XII Encontro Nacional de Economia Política, 2007, São Paulo. Anais do XII Encontro Nacional de Economia Política, 2007.

FISHLOW, Albert. "Lessons from the Past: Capital Markets during the 19th Century and the Interwar Period”, International Organization, MIT Press, vol. 39 (3), 1985. p. 383-439.

FRIEDEN, Jeffry. Capitalismo Global: História econômica e política do século XX. Rio de janeiro. Editora Zahar, 2008.

FRITSCHER, André Martínez e MUSACCHIO, Aldo. "Endowments, Fiscal Federalism, and the Cost of Capital for States: Evidence from Brazil, 1891-1930”. Cambridge: NBER Working Paper, $n^{\circ}$ 15,411, October, 2009.

GOLDSMITH, Raymond W. Brasil 1850-1984: Desenvolvimento Financeiro sob um Século de Inflação. São Paulo: Editora Harper \& Row do Brasil Ltda, 1986.

HOCKING, Brian. Localizing Foreign Policy. New York: St. Martin’s Press, 1993.

KEOHANE, Robert O. and NYE, Joseph Jr. 1977/2001: Power and Interdependence: World Politics in Transition. 3rd edition: New York: Addison-Wesley Longman.

LOPREATO, Francisco Luiz. “O endividamento dos governos estaduais nos anos 90”. Texto para Discussão. IE/UNICAMP, Campinas, n 94, março 2000.

PRIETO, Noé Cornago. O outro lado do novo regionalismo pós-soviético e da Ásia-Pacífico. In: VIGEVANI, Tullo (Org.). A dimensão subnacional e as relações internacionais. São Paulo: Unesp, 2004.

SOLDATOS, Panayotis. "An Explanatory Framework for the Study of Federated States as Foreignpolicy Actors" In: Federalism and International Relations: the role of subnational units /Ed: Hans MICHELMANN e Panayotis SOLDATOS. Oxford: Claredon Press, 1990.

TORRES, Alberto. A Organização Nacional. Rio de Janeiro: 1914; reimpressão: Brasília, Ed. Universidade de Brasília, 1982.

WHITAKER, José Maria. A administração Financeira do Governo Provisório de 4 de novembro de 1930 a 16 de novembro de 1931. Rio de Janeiro: E. G. Revista dos Tribunaes, 1933.

\section{Fontes documentais oficiais}

Diário Oficial da União, 3 de setembro de 1890, p. 3.891.

Diário Oficial da União, 22 de novembro de 1918, p. 13.861.

Relatório do Presidente da Província da Bahia à Assembleia Legislativa, 1888.

Relatório do Presidente do Estado do Espírito Santo à Assembleia Legislativa, 1894 e 1896.

Mensagem do Presidente do Estado de Minas Gerais à Assembleia Legislativa, 1897.

Mensagem do Presidente do Estado de São Paulo à Assembleia Legislativa, 1900 e 1906.

Mensagem ao Congresso Nacional pelo Presidente da República, Dr. Francisco de Paula Rodrigues Alves, edições de 1903, 1905 e 1906.

Relatório do Ministro da Fazenda Rivadavia da Cunha Corrêa, 1914.

Recebido em 29 de setembro de 2011 Aprovado em 26 de outubro de 2011 


\title{
Resumo
}

Neste artigo, visa-se a analisar um caso de extroversão de governos estaduais no campo do financiamento externo no período da chamada República Velha (1890-1930) no Brasil. Com base na definição de "paradiplomacia financeira", argumenta que a experiência histórica brasileira nesse aspecto teria sido um caso típico de ação paradiplomática. Amplo levantamento estatístico dos empréstimos externos por estados, o resgate das fontes documentais primárias sobre o assunto e a contextualização histórica pertinente dão sustentação à caracterização do período como uma fase de paradiplomacia financeira precoce.

Palavras-chave: descentralização federativa; empréstimos externos; paradiplomacia financeira.

\begin{abstract}
This article aims to analyze a case of outward-bound move of state governments in the realm of external loans during the period of the so-called Old Republic (1890-1930) in Brazil. Based on the definition of "financial paradiplomacy," it argues that the Brazilian historical experience in this regard would have been a typical case of paradiplomatic action. Broad statistical survey of foreign loans borrowed by states, the rescue of primary sources about the subject and historical perspective give relevant support to characterize the period as a time of early financial paradiplomacy.
\end{abstract}

Keywords: federative decentralization; foreign loans; financial paradiplomacy. 